ЛОГВИНОВ Виктор Николаевич - заслуженный архитектор РФ, член-корреспондент Российской академии архитектуры и строительных наук, действительный член Международной академии архитектуры, первый вице-президент Союза архитекторов России, руководитель мастерской ООО «Творческая мастерская архитектора Логвинова» (tma.logvinova@gmail.com)

\title{
УДИВИТЕЛЬНЫЕ ПРИКЛЮЧЕНИЯ УРБАНИЗМА В РОССИИ
}

\begin{abstract}
Аннотация. Один из виднейших архитекторов современной России в острой публицистической форме размышляет о состоянии градостроительства в РФ. Особое внимание уделяется достоинствам и недостаткам советского градостроительства. Дурным в СССР было не «градостроительство», высокий научный уровень теории которого был признан во всем мире, а его реализация в конкретных формах зданий на очень низком уровне культуры строительства: «типовуха", некомплексность застройки, стремление к повышению этажности и т.д. Но сегодня, став источником огромных прибылей нового правящего класса, неразрывно связанного с властью, эти особенности на десятилетия определили характер градостроительного развития огромной страны - особенности урбанизма по-русски. Крупнейшая страна мира с самыми большими территориальными ресурсами выбрала для себя путь, характерный для перенаселенных карликовых государств-городов: сверхурбанизацию азиатского типа. Автор показывает, что задача, поставленная высшим руководством, а именно сбалансированное гармоничное пространственное развитие России, невозможна при сохранении этой линии.

Ключевые слова: градостроительство, советское градостроительство, градостроитель, урбанизм, урбанистика, урбанизация, расселение, бизнес, национальная идея
\end{abstract}

Не ищите смысла там, где есть умысел. Народная мудрость.

$\mathrm{B}_{r}^{\text {A }}$ дни проведения IX Московского урбанистического форума (Moscow Urban Forum) невольно вспомнился прошлогодний форум, отмеченный знаменательным событием. Тогда на VIII Московском урбанистическом форуме выступил с 15-минутным докладом сам президент России В.В. Путин! Это при том, что за все годы президентства он ни разу не касался этой сферы и не посетил ни одного профессионального форума, посвященного вопросам градостроительства и (или) архитектуры. А тут вдруг за неполный год не менее 5 раз в официальных речах и документах президент акцентировал внимание на вопросах сбалансированного, гармоничного пространственного развития России, транспортной инфраструктуры, общественных пространств, качества жилья и городской среды. По сути, это была презентация концепции пространственного развития России, где нашлось место и малым городам, и сельским территориям, сохранению их самобытности, идентичности, уникальности - т.е. всему тому, что на предыдущих форумах предлагалось стереть с лица нашей благословенной земли, оставив на ней только редкую цепочку городов-миллионников.

Так может это и есть новый урбанизм? По-русски? Слово «урбанизм» имеет туманное и неоднозначное прочтение. Легче перечислить, что не может называться урбанизмом. Это не процесс образования и развития городов (по-русски - процесс градостроительства), который называется в мире урбанизацией. Это не наука, т.к. раздел экономической географии, изучающий город как систему, называется урбанистикой (градоведением). Это не практика городского (градостроительного) планирования, т.к. во всех международных классификатоpax видов деятельности (ООН, ВТО, ЕС, МСА) urban planning является одной из профессиональных услуг архитекторов. Урбанист - это и не приверженец 
городского образа жизни, т.к. с легкой руки Ф.Л. Райта человек, который не может жить вне города с его толчеей, шумом и выхлопными газами, называется урбаноидом.

Наконец, так не может называться предмет профессиональной деятельности, так как урбанизмом, инжинирингом и дизайном среды, в отличие от градостроительства, инженерии и архитектуры, так же как мастер-планом и дизайн-кодом, может заниматься кто угодно - без специального образования и опыта. Профессии «урбанист», в отличие от профессии «градостроитель», нет в списках профессий Минтруда и Минобразования; урбанистов не выпускает ни один вуз страны.

Похоже, что термин «урбанизм» означает не конкретные дела, общественные институции или научные доктрины, а некое общее направление умонастроения, направленное на Запад. И посему им можно назвать все что угодно. Например, вслед за Википедией можно утверждать, что урбанизм «иногда применяется как символ градостроительства в целом».

Так может, правы те, кто утверждает, что «урбанист - это градостроитель с нетрадиционной профессиональной ориентацией»? И что урбанист-западник с его, конечно же, прогрессивными либеральными взглядами должен заменить отечественного ретрограда-градостроителя? Ведь всем представителям элиты прекрасно известно, что все с Запада - хорошо, а все отечественное (включая язык) - плохо.

Как помнится из уроков марксизма-ленинизма, практика есть критерий «истинности, посюсторонности нашего мышления». И только практика на нашей грешной почве может дать ответ на самые замысловатые вопросы. А наш, русский урбанизм наверняка имеет свое лицо, сформировавшееся под влиянием нашей истории и географии.

\section{История с географией}

В Советском Союзе не было ни секса, ни урбанизма. Но дети и города рождались! Потому как была любовь и очень уважаемая, серьезная научно-практическая профессиональная деятельность государственной важности, называемая градостроительством.

Высокий научный уровень советской теории градостроительства признан в мире. Ругая сегодня все советское, включая градостроительство, нынешняя элита явно запуталась в терминах. Дурным у нас было не градостроительство как таковое, а его реализация в конкретных формах зданий на очень низком уровне культуры строительства, т.е. качество архитектуры зданий массовой жилой застройки - та самая «типовуха», которая нанесла культуре России колоссальный ущерб, изуродовав на столетие облик советских городов.

Дурное архитектурное воплощение может дискредитировать самые прекрасные и гуманные градостроительные идеи. Однообразие и унылость советских городов есть следствие «типовухи», а не ошибочности градостроительных идей. На бумаге в градостроительных планах всех уровней все было правильно. И в тех редких случаях, когда они хотя бы частично, но выполнялись на терпимом уровне качества строительства и благоустройства (например, в Прибалтике или в Северном Чертаново), качество жилой среды советских городов было на голову выше, чем во многих современных районах.

Беда в том, что такие примеры очень редки, а в полной мере ни один генплан города так и не был реализован. Некомплексность застройки - вторая после «типовухи» напасть советского градостроительства, но и эта беда блекнет в сравнении с «детской болезнью» урбанизации - ростом этажности многоквартирных жилых домов. 
Зарядив 500 домостроительных комбинатов на выпуск одинаковых типовых коробок, советская власть предопределила единственный путь развития типового проектирования - стремительный рост этажности при медленном росте качества архитектуры. Не обращая внимания на требования СНИПа об ограничении этажности застройки 9 этажами, отметки в 12, 14, 16, 22, 25 этажей были преодолены в течение первых 15 лет индустриализации строительства. Это был самый простой путь выполнения планов по увеличению объемов типового строительства (индивидуальное практически было запрещено). Слегка затормозив на отметке в 25 этажей из-за отсутствия норм и необходимой пожарной техники, рост этажности перешел в наследие от социализма к капитализму, так же как другая уникальная особенность социалистического градостроительства - явный приоритет многоквартирного жилища.

Программно объявив частную собственность социальным злом, фактически государство развивало только строительство жилища «коллективного типа» - многоквартирных домов. Эта специфическая особенность, как ни парадоксально, перешла в наследие от социализма к капитализму, наложившись при этом на другой социально-психологический феномен постсоветского периода - «национальную идею» советского человека.

\section{Идеи как товар}

Утверждение, что у советских людей не было никакой «национальной идеи», кроме построения коммунизма для всех, неверно. Национальная идея была, но не одна, а целых четыре идеи, живущие в каждой советской семье. Назывались они «квартира», «машина», «дача» и самая трудная, но главная и заветная «переехать в Москву». Или, на худой конец, в Ленинград. Ведь эти города были ближе всего к воплощению того, что грезилось в коммунистическом завтра. Здесь и асфальт, и колбаса, и культура - театры с музеями и видами на высотки или шпиль Адмиралтейства. Жаль только, что реализовать эту идею могли только счастливчики из провинциальной советской номенклатуры, да лимитчики, готовые заплатить за мечту десятками лет тяжелого труда и жизни в бараках и общежитиях.

Но прописка ушла, а пришла демократия - национальная идея № 4 стала доступной для всех. Вся опустевшая гигантская страна устремилась на крошечный $(0,05 \%)$ участок своей территории - в столицы и их ближайшие окрестности, требуя в первую очередь жилья (с остальным разберемся позже). Тощие земли столиц неожиданно стали сверхплодородными. Выражаясь поэтически, не для злаков, а денежных знаков.

Идея стала товаром. Капитализм монетизировал стремление $70 \%$ населения России переехать в столицу через скрытую земельную ренту, которая в среднем в столицах составляет $2 / 3$ стоимости любой недвижимости. И чем ближе к Кремлю или Зимнему дворцу, тем больше земельная рента, дающая прибыль больше 300\%. При таком куше, как известно, «нет такого преступления, на которое он (капитал) не рискнул бы, хотя бы под страхом виселицы». За распил этого куша идет скрытая жестокая борьба (без правил) между инвесторами, банками, девелоперами и властями всех уровней.

Какое тут градостроительство? Какая архитектура? Какие права граждан на благоприятную среду? Надо увеличить Москву вширь в 2-3 раза, переселив в нее еще миллионов 10-15. Это же какая выгода! В Новой Москве нет инфраструктуры? И работать негде? Жаль. Тогда надо увеличить Москву ввысь, снеся пятиэтажки. 


\section{Урбанизм по-русски}

Вот тут и пригодился весь опыт, накопленный типовым советским строительством. И обнаружилось, что мешает осуществлению новой капиталистической мечты (выросшей из старой коммунистической идеи) сущая мелочь - нормы плотности. Нормы плотности жилого фонда (микрорайона при этажности в 16-20 этажей), ограниченные СНИПом 1975 г., - 7500 кв. м на 1 га были решительно отброшены, и плотность стремительно полетела вверх: 10 000, 15 000, 20 000, 25000 кв. м на гектар и далее без остановки, невзирая на инсоляцию, санитарные разрывы, обеспеченность парковками и соцкультбытом, масштабность, а зачастую и просто всякий здравый смысл. Так случилось и с хорошо знакомой из мирового и отечественного опыта квартальной застройкой. Отмена микрорайонного принципа застройки, объявленного рудиментом проклятого социалистического прошлого, послужила поводом отменить все нормы плотности, что дало возможность увеличить ее и, соответственно, сбор земельной ренты многократно.

Действительно, высокоплотная периметральная квартальная застройка широко применялась во всем мире на протяжении столетий. Но только при этажности до 6, очень редко - в 7-8 этажей. Ни в Нью-Йорке, ни в Сингапуре - нигде в мире нет многоэтажной периметральной квартальной застройки. А в Москве есть, например в новом, широко разрекламированном жилом комплексе «Царская площадь» с рекордной, просто немыслимой в нормальных условиях жизни плотностью застройки около 55000 кв. м на гектар!

На одном из самых шумных и загазованных участков столицы, на пересечении Третьего транспортного кольца и Ленинградского проспекта, на месте снесенного стадиона Юных Пионеров построен комплекс кварталов-каре из домов высотой до 20 этажей с дворами-колодцами, глубина которых вдвое больше их ширины. Это, можно сказать, невиданный в мире вклад московского урбанизма в сокровищницу шедевров искусства...

По примерным подсчетам, прибыль, снятая с 5,7 га этого явно не элитного московского участка, может составить около 40 млрд руб. Даже если отдать, как заведено, половину прибыли городу, остается сумма раза в полтора большая, чем весь годовой бюджет такой республики, как Калмыкия, с площадью в полтора миллиона раз большей, чем комплекса.

Из всех возможных путей развития системы расселения (урбанизация, дезурбанизация, субурбанизация, новый урбанизм) крупнейшая страна мира с самыми большими территориальными ресурсами выбрала для себя путь, характерный для перенаселенных карликовых государств-городов. Вернее, ее самую тяжелую и бесчеловечную форму - сверхурбанизацию азиатского типа. Правда, это только для столиц, куда стекаются денежные потоки от приверженцев национальной идеи № 4. В меньшей степени - для дюжины мегаполисов, рассматриваемых населением как промежуточные станции на пути в столицу. Половина населения страны, каким-то чудом живущая еще в малых городах и сельских поселениях, обречена на самовыживание, оставшись без «крови экономики» - денег (бюджета, займов, инвестиций, ипотеки) и... работы.

Рудименты индустриализации советского строительства, с одной стороны, и последствия политики построения «витрины социализма» в отдельно взятом столичном городе - с другой, в условиях ничем не регулируемого свободного рынка недвижимости (земля и жилище в городах) дали невиданные плоды. Став источником огромных прибылей нового правящего класса, неразрывно связанного с властью, эти особенности на десятилетия определили характер градостроительного развития огромной страны - особенности урбанизма по-русски. 
По-большевистски решительно и громогласно отрекшись от старого (социалистического) мира, российский капитализм во второй своей редакции отобрал из практики социализма самое плохое, но самое прибыльное. В результате градостроительство России пошло в направлении прямо противоположном направлению развития Европы и Северной Америки и в сфере расселения, и в этажности застройки, и в структуре жилого фонда, и в архитектуре.

Вместо равномерного, сбалансированного, гармоничного развития всей страны, что является краеугольным камнем политики расселения любого развитого государства, предлагается переселить всех граждан России из малых и средних городов в два десятка мегаполисов.

Вместо разумного, социально и медицински обоснованного ограничения этажности жилой застройки 6-7 этажами, как в Европе, все крупные города России стали строить 25-этажные и более высокие жилые дома, хаотично торчащие в исторических центрах этих городов и в их ближайших пригородах. Вместо политики государственной помощи строительству самого комфортного и дешевого (в строительстве и эксплуатации) типа жилища - индивидуальных домов, - доля строительства которых в Европе и США составляет 65-70\%, в России поддерживается только строительство многоэтажных, многоквартирных «человейников». Под предлогом дороговизны инфраструктуры для индивидуальной застройки государство бросило этот сектор строительства на произвол судьбы, закрепляя тем самым ненормальную тенденцию, при которой доля частных индивидуальных домов в структуре жилого фонда России составляет всего $20 \%$.

В ответ на поставленные президентом РФ задачи, такие как «повышение эстетической ценности архитектурной среды российских городов, государственная поддержка архитектурного творчества, признание архитектуры социально значимым видом искусства», а также игнорируя его призывы к «сохранению индивидуальности и самобытности российских городов», предлагается принять закон, реанимирующий «типовое проектирование» путем до боли знакомого тотального запрета государственным и муниципальным заказчикам строить по «не типовым», т.е. индивидуальным, проектам.

Для реализации всех этих изобретений российского урбанизма профессиональные градостроители и архитекторы не нужны. Более того, они еще и мешают получать максимальную прибыль, бубня что-то про разумное расселение, качество среды, плотность, комфорт и эстетическую ценность. Профессию «градостроитель» убрали с дороги просто и изящно: в тендерах на разработку градостроительной документации может участвовать кто угодно - с любым образованием и опытом и совсем без оного, став тем самым «урбанистом». Не связанные какими бы то ни было профессиональными знаниями и обязательствами, новые «специалисты» за скромное вознаграждение готовы свободно воплощать любые, самые губительные для общества урбанистические идеи.

Вот он, момент истины: урбанизм по-русски, идущий на смену градостроительству, - это только большой или маленький бизнес (на земельной ренте)! Если для тебя градостроительство - это творческая научно-практическая деятельность и ответственная общественная миссия, то ты - «градостроитель». Если для тебя это только бизнес, то ты - «урбанист». И ничего личного (и, тем более, общественного). Только бизнес!

Не ищите смысл там, где есть умысел.

\section{Эпилог к эпопее}

Рассмотрев приключения урбанизма на российской почве, можно, наконец, нарисовать портрет российского урбаниста, ответив на поставленный в начале 
статьи вопрос. Блиц-анализ выступлений и практики участников Московского урбанистического форума показал, что наш урбанист очень разнообразен по профессии и в своем большинстве не имеет никакого отношения к профессии градостроителя. Самыми известными урбанистами России являются крупные государственные топ-менеджеры и бизнесмены-землевладельцы (часто в одном лице), зарабатывающие деньги на урбанизации по-русски. Теперь, наконец, можно перевести этот туманный термин из Туманного Альбиона: «урбанист» (по-русски) - видный представитель российской элиты, не отягощенный какими-либо знаниями о градостроительстве, но убежденный, что только в среде мегаполиса можно делать большой бизнес».

Эта идея на практике заслонила и заменила все градостроительные и урбанистические идеи о гуманном городе, качестве среды, участии населения в управлении развитием города, которые в изобилии рождаются в мире и сообщаются на Московском урбанистическом форуме нашими западными коллегами.

Сама история России наводит на мысль, что наша Родина выполняет в мире чрезвычайно важную, но необычную миссию: рьяно берясь за реализацию самых передовых мировых идей, правящий класс страны избирательно применяет только выгодные для себя пути реализации этих идей. Радикализируя и бюрократизируя мировые идеи в гигантских масштабах, Россия показывает всему миру, как не надо делать, предостерегая тем самым мир от пути, по которому не надо идти. Так же обстоит дело и с урбанизмом. Урбанизмом по-русски.

LOGVINOV Viktor Nikolaevich, Honored Architect of Russia, Corresponding Member of Russian Academy of Architecture and Construction Sciences, Member of the International Academy of Architecture, first Vice-president of the Union of Architects of Russia, Head of the Workshop «Architect Logvinov Creative Workshop» (tma.logvinova@gmail.com)

\title{
AMAZING ADVENTURES OF URBANISM IN RUSSIA
}

\begin{abstract}
One of the most prominent architects of modern Russia in an acute journalistic form reflects on the state of urban development in the Russian Federation. The article pays particular attention to the advantages and disadvantages of Soviet urban development. The high scientific level of the theory of Soviet urban planning was famous all over the world, although its implementation in specific forms of buildings at a very low level of construction culture, such as typical construction, building uncomplexity, the desire to increase the number of storeys, etc., was bad. Nevertheless, today, having become a source of huge profits for the new ruling class, inextricably linked with the authorities, these features for decades have determined the nature of urban development of a huge country - the peculiarities of urbanism in the Russian style. The largest country in the world with the largest territorial resources has chosen for itself the path characteristic of overpopulated dwarf city-states: Asian over-urbanization. The author shows that the task set by the top leadership, namely balanced harmonious spatial development of Russia is impossible while maintaining this line.
\end{abstract}

Keywords: urban planning, Soviet urban planning, urbanism, urban studies, urbanization, resettlement, business, national idea 